\title{
POMNIK HISTORII - PROCEDURY UZNANIA I KRYTERIA WYBORU NA PRZYKŁADZIE MIASTA TRZEBIATÓW, PRETENDENTA D0 TYTUŁU
}

\section{LATOUR Agnieszka ${ }^{1}$}

\footnotetext{
${ }^{1}$ Agnieszka Latour, Wojewódzki Urząd Ochrony Zabytków w Szczecinie https://orcid.org/0000-0002-7940-6681
}

ABSTRAKT:WniosekBurmistrza Trzebiatowa wsprawieuznaniazespołu staromiejskiego w Trzebiatowie za pomnik historii został przekazany Ministrowi Kultury i Dziedzictwa Narodowego w kwietniu 2011 r. Do tej pory nie nastąpiło rozstrzygnięcie w tej sprawie.Trzebiatów to miasto położone w powiecie gryfickim, w województwie zachodniopomorskim. Podstawą do złożenia wniosku o przyznanie tytułu Pomnika Historii były:

- Zachowany średniowieczny układ urbanistyczny zespołu staromiejskiego z czytelnym podziałem katastralnym;

- Zachowana historyczna zabudowa w obrębie murów obronnych,

- Wpis terenu Starego Miasta do rejestru zabytków;

- 40 obiektów w granicach Starego Miasta wpisano do rejestru;

- Na terenie Starego Miasta obowiązuje miejscowy plan zagospodarowania przestrzennego w formie planu rewaloryzacji, uchwalony przez Radę Miasta Trzebiatowa w $1996 \mathrm{r}$.

Przywołano procedury uznania i kryteria wyboru pomnika historii. Przedstawiono zarys historii miasta oraz działania konserwatorskie i planistyczne, wskazując przy tym jego wartości materialne i niematerialne. W konkluzji wyrażono przekonanie, że wymienione wartości spełniają kryteria wyboru postawione przez MKiDN.

SŁOWA KLUCZE: Pomnik Historii, stare miasto, Trzebiatów, zabytki

\section{Tytułem wstępu}

Wniosek Burmistrza Trzebiatowa, opracowany przez Oddział Terenowy Narodowego Instytutu Dziedzictwa w Szczecinie, w sprawie uznania zespołu staromiejskiego w Trzebiatowie za pomnik historii został przekazany Ministrowi Kultury i Dziedzictwa Narodowego za pośrednictwem Zachodniopomorskiego Wojewódzkiego Konserwatora Zabytków w kwietniu 2011 r. ${ }^{1}$ Do tej pory nie nastąpiło rozstrzygnięcie w tej sprawie. Na pytania wystosowane przez Burmistrza, przesyłane 
w kolejnych latach, przychodziły odpowiedzi niezbyt precyzyjne i niewiele wyjaśniające. W 2014 r. poinformowano, że: „wniosek dotyczący Trzebiatowa jest obecnie jednym z najstarszych pośród oczekujących (...) rozpatrywanie wniosków o uznanie za pomniki historii założeń miejskich jest niezwykle czasochłonne i skomplikowane"2.

W 2015 r. poinformowano, że: „prace nad przygotowaniem opinii merytorycznej co do zasadności w/w propozycji (wpisu) są zaawansowane i w normalnym trybie procedura powinna być na ukończeniu. Opóźnienie wynika z faktu, że na ostatnim posiedzeniu w grudniu 2014r. Rada Ochrony Zabytków podjęła decyzję o potrzebie modyfikacji kryteriów i procedur uznawania obiektów za pomniki historii i o nierozpatrywaniu wniosków do momentu przyjęcia nowego regulaminu".

Nie określono jednak, kiedy ta modyfikacja nastąpi.

W 2018 r. odpowiedź brzmiała: „uprzejmie informujemy, że prowadzone są prace nad pogłębioną, czasochłonną analizą wniosku potrzebną w przypadku problematyki historycznych założeń miejskich. Przewidziana jest również wizja lokalna z udziałem przedstawicieli NID, która będzie stanowiła końcowy etap oceny"4.

Pod koniec 2018 r., z okazji stulecia odzyskania niepodległości, uznano za pomniki historii kolejnych 14 obiektów, jednak nie znalazł się wśród nich zespół staromiejski w Trzebiatowie. Nie pojawiła się też żadna informacja ze strony MKiDN w sprawie postępowania dotyczącego Trzebiatowa.

\section{Procedury uznania i kryteria wyboru ${ }^{5}$}

Aby uzyskać miano pomnika historii należy spełnić kryteria, które są weryfikowane według określonych procedur. Poniżej zestawiono oba te elementy.

\section{Procedury uznania:}

- Propozycję uznania za pomnik historii, wraz z właściwą dokumentacją, zgłaszający składa do Ministra Kultury i Dziedzictwa Narodowego za pośrednictwem i po zaopiniowaniu przez wojewódzkiego konserwatora zabytków;

- Departament Ochrony Zabytków MKiDN kieruje zgłoszenie do NID w Warszawie w celu weryfikacji danych zawartych w dokumentacji i wydania opinii co do zasadności propozycji uznania obiektu za pomnik historii;

- Zaopiniowane przez NID zgłoszenie MKiDN przedkłada Radzie Ochrony Zabytków;

- Po wyrażeniu pozytywnej opinii przez Radę Ochrony Zabytków, Departament Ochrony Zabytków przekazuje dokumentację zgłoszenia do NID, który przygotowuje projekt rozporządzenia Prezydenta RP wraz z uzasadnieniem i załącznikiem graficznym;

\footnotetext{
Pismo MKiDN z dnia 7.08.2014 r., znak: DOZ/3906/14, DOZ-SK. MFW-6611/1-4/14.

Pismo MKiDN z dnia 25.03.2015 r., znak: DOZ/1266/15, DOZ-SK.MFW-6611/1-4/14.

Pismo NID z dnia 29.01.2018 r., znak: NID-SBOD/806/111/18/AW.

Na podstawie informacji dostępnych na stronie internetowej NID.
} 
- Po dokonaniu analizy projektu rozporządzenia Departament Ochrony Zabytków przekazuje go Ministrowi KiDN do ostatecznej akceptacji;

- MKiDN kieruje do Prezydenta RP wniosek o uznanie obiektu za pomnik historii;

- Po akceptacji Prezydent RP w drodze rozporządzenia uznaje obiekt za pomnik historii określając jego granice;

- Rozporządzenie Prezydenta RP jest ogłaszane w Dzienniku Ustaw.

Kryteria wyboru:

- Uznanie zabytku za pomnik historii jest szczególną formą nobilitacji. Zgłaszać można zabytek nieruchomy:

- o znaczeniu ponadregionalnym,

- o dużych wartościach historycznych, naukowych i artystycznych,

- mający znaczenie dla polskiego dziedzictwa kulturowego,

- utrwalony w świadomości społecznej,

- stanowiący źródło inspiracji dla kolejnych pokoleń.

Obiekt, zespół, układ przestrzenny lub obszar proponowany do uznania za pomnik historii musi być wpisany do rejestru zabytków lub objęty statusem parku kulturowego. Dla układów przestrzennych i obszarów winny być uchwalone miejscowe plany zagospodarowania przestrzennego.

Ponadto muszą to być zabytki, które:

- zachowały pierwotną kompozycję przestrzenną lub uległy nieznacznym przekształceniom,

- są jednorodne stylowo lub o czytelnych i zharmonizowanych ze sobą nawarstwieniach,

- są należycie wyeksponowane w przestrzeni miejskiej lub krajobrazie i zachowały pierwotne relacje $\mathrm{z}$ otoczeniem,

- są dziełami wybitnych twórców,

- są dobrze zachowane lub w stanie pozwalającym na ich rewaloryzację,

- są przedmiotem troski konserwatorskiej.

\section{Trzebiatów pomnikiem historii}

Trzebiatów to miasto położone w powiecie gryfickim, w województwie zachodniopomorskim, w zakolu rzeki Regi, nieopodal wybrzeża Bałtyku, $10 \mathrm{~km}$ od portu i letniskowej nadmorskiej osady Mrzeżyno.

Podstawą do złożenia wniosku o przyznanie tytułu pomnika historii były:

- Zachowany w nieomal nienaruszonym stopniu średniowieczny układ urbanistyczny zespołu staromiejskiego;

- Czytelny dawny podział katastralny oparty na module pręta lubeckiego (4,5 m), niezatarty 
przy powojennych odbudowach lub uzupełnianiu pierzei (fot. 1);

- Zachowana w dużej części historyczna zabudowa w obrębie murów obronnych, co jest ewenementem na Pomorzu Zachodnim;

- Ochrona konserwatorska w formie wpisu terenu Starego Miasta do rejestru zabytków ${ }^{6}$;

- Oprócz terenu Starego Miasta istnieje 40 obiektów w jego granicach wpisanych do rejestru zabytków ${ }^{7}$;

- Na terenie Starego Miasta obowiązuje miejscowy plan zagospodarowania przestrzennego w formie planu rewaloryzacji Starego Miasta, uchwalony przez Radę Miasta Trzebiatowa w 1996 r $^{8}$

Teren proponowany do tytułu Pomnika Historii pokrywa się z granicami wpisu do rejestru zabytków.
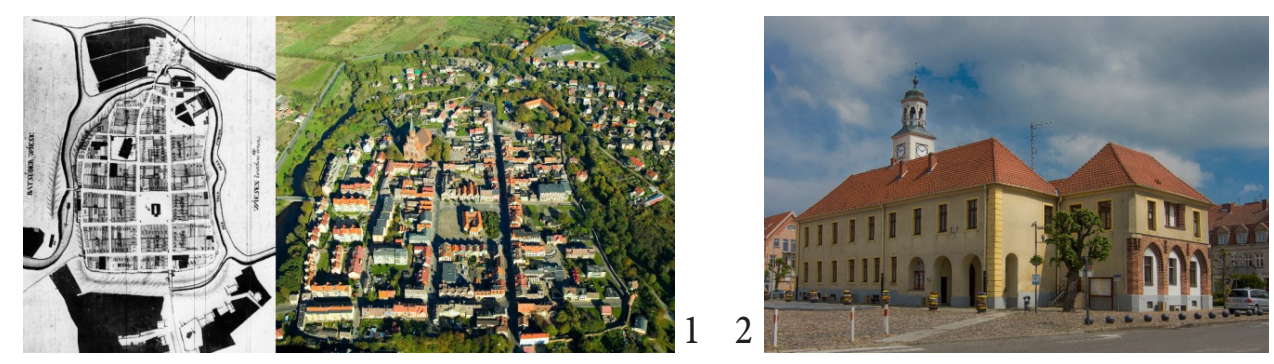

Fot. 1 Trzebiatów. Dawny podział katastralny (ryc. z 1730 r.) w zestawieniu z widokiem współczesnym z lotu ptaka, od strony zachodniej (fot. archiwum miasta Trzebiatowa)

Fot. 2 Trzebiatów. Ratusz staromiejski z widocznymi średniowiecznymi reliktami murów (fot. C. Dubiel)

\section{Zarys historii Trzebiatowa ${ }^{9,10}$}

Szczególne nasilenie osadnictwa na Pomorzu Zachodnim nastąpiło w okresie wczesnego średniowiecza. Korzystne warunki dla rozwoju rolnictwa w dolinach rzek Odry, Iny, Regi i Parsęty stanowily podstawę szybkiego rozwoju osad, szczególnie w rejonie Pyrzyc, Trzebiatowa, Kołobrzegu, Białogardu, Nowogardu, Stargardu i Kamienia Pomorskiego.

Badania archeologiczne przeprowadzone w Trzebiatowie, odkrywające osadę rzemieślniczohandlową w miejscu usytuowania późniejszego klasztoru Norbertanek, a dzisiejszego pałacu z siedzibą Trzebiatowskiego Ośrodka Kultury, wskazują na osadnictwo okresu od połowy XI do połowy XIII w.

\footnotetext{
6 Nr rej. 72, znak Kl.V.-0/54/55 z dnia 1955-10-29.

7 Karta obiektu zabytkowego zawiera listę obiektów zabytkowych indywidualnie wpisanych do rejestru zabytków usytuowanych w granicach Starego Miasta w Trzebiatowie.

8 Uchwała Nr XXIX/210/96 Rady Miejskiej w Trzebiatowie z dnia 30 grudnia 1996 r. w sprawie zmiany miejscowego planu zagospodarowania przestrzennego miasta Trzebiatowa $\mathrm{w}$ formie planu rewaloryzacji Starego Miasta, Dziennik Urzędowy Województwa Szczecińskiego nr 3, z dnia 12 marca 1997 r.

$9 \quad$ Latour S., 1981 r., s. 66.

10 Wniosek o przyznanie tytułu pomnika historii złożony do MKIDN.
} 
Wzmiankowana historia grodu (castrum) Tribetov sięga roku 1170, kiedy to książę dymiński Kazimierz wystawił dokument fundacyjny dla zakonu norbertanów przybyłych do nieodległych Białoboków z Lund ${ }^{11}$. Około 1187 r. Trzebiatów z okolicznymi wioskami otrzymała jako wdowie uposażenie księżna Anastazja, córka księcia polskiego Mieszka III Starego, żona księcia Bogusława I, matka Kazimierza II i Bogusława II. W 1224 r. księżna wydała dokument przekazujący Trzebiatów z karczmą i kościołem żeńskiemu klasztorowi norbertanek. Do przejęcia grodu jednak nie doszło, a zakonnice osiedliły się wówczas w pobliskim Wyszkowie, gdzie przebywały do $1285 \mathrm{r}$. Wnuk Anastazji, Warcisław III sprzedaje Trzebiatów norbertanom w $1242 \mathrm{r}^{12}$ Było tam wówczas obszerne targowisko z kościołem i karczmą. Miasto dysponowało wówczas wodami rzeki Regi aż do ujścia, co miało niebagatelne znaczenie dla jego rozwoju. W 1277 r. Barnim I i jego syn Bogusław IV nadają Trzebiatowowi lubeckie prawo miejskie. W1281 r. potwierdzono tę lokację, przy czym mieszkańcy otrzymali wolności celne i uprawnienia handlowe. Obok pełnionych funkcji rolniczych i handlowych Trzebiatów spełniał znaczącą rolę w systemie obronnym Księstwa Zachodniopomorskiego zarówno w XII w., jak i po jego podziale na Księstwo Szczecińskie i Wołogosko-Słupskie. Sprzyjały temu doskonałe naturalne warunki obronne, utworzone przez rozlewiska rzeki Regi i rozległe bagniska w jej sąsiedztwie. Ze znaczeniem obronnym miasta wieże się zezwolenie udzielone w 1299 r. przez księcia Bogusława IV na wzniesienie przez mieszczan systemu obronnego o murowanej konstrukcji, który miał zastąpić przypuszczalnie dotychczasowe obwałowania drewniano-ziemne ${ }^{13}$. W I połowie XIV w. powstał pełny pierścień murów z czterema bramami, wzmocniony systemem baszt i czatowni. Zapewniały one ochronę przed napadami „rycerzy - rabusiów” lub zawistnych mieszkańców sąsiednich Gryfic i Kołobrzegu, które organizowano na tle zatargów gospodarczo-handlowych. Dzięki obwarowaniom tym zostały dwukrotnie odparte oblężenia wojsk brandenburskich w 1631 i 1637 roku. Na znaczny wzrost zamożności mieszczan od XIV (w tym czasie miasto należało już do Hanzy) do XVI w. składały się dochody z uprawy ziemi, hodowli, browarnictwa i rybołówstwa (też morskiego). Szczególną rolę miał handel zbożem prowadzony na międzynarodową skalę. Uzyskane w 1303 r. prawo składu dla spławianych Regą towarów, własna flota morska licząca 22 statki, własny port w Redzeujściu oraz uzyskane w 1309 r. zwolnienie z cła z połowów na pobrzeżu Bałtyku na obszarze od ujścia Świny do ujścia Regi sprawiło, że Trzebiatów stał się silnym ośrodkiem utrzymującym kontakty handlowe z Gdańskiem, Rugią, Bornholmem, Lubeką i Kopenhagą. Wzrost zamożności mieszkańców odznaczył się w budownictwie. Powstały wówczas ratusz (fot 2), jako siedziba władz miejskich, kościół farny, trójnawowy halowy, budynki szpitalne z kaplicami, liczne murowane domy mieszczańskie. Obszar miasta w granicach średniowiecznych fortyfikacji wynosił 35 ha. Zyskało ono regularny, czytelny do dziś układ szachownicowy (fot.1), o kwartałach podzielonych na wąskie, głębokie

\footnotetext{
11 Dokument fundacyjny wydany przez ks. Kazimierza I. W dokumencie wymieniono m.in. patronat nad kościołem w Trzebiatowie. Ślaski K., Podziały terytorialne na Pomorzu w XII-XIII w., Poznań 1960, s.109.

12 Warcisław III sprzedał klasztorowi w Białobokach: "vicum Trebetove cum taberna et villam in Stresko et villam Cricuz, et aquam liberam usque ad potrum maris [...], Pommersches Urkundenbuch, Szczecin, t.I, s. 322. 13 Wynika to $\mathrm{z}$ treści dokumentu „Libertarimas civitatem nostram Treptov ...”, Pommersches Urkundenbuch, Szczecin, t.I, s. 358.
} 
działki, zabudowane od frontu murowanymi kamienicami, usytuowanymi często szczytami do ulicy. Dwa kwartały zostały przeznaczone pod budynki użyteczności publicznej tj. ratusz i kościól, miejsce trzeciego zajął klasztor, późniejszy pałac. Rynek o wymiarach 96x105 m przesunięty został do środka założenia w kierunku południowo-zachodnim. Relikty XV-XVIwiecznej zabudowy są nadal widoczne w niektórych elewacjach oraz w piwnicach istniejącej zabudowy.

W 1534 r. w Trzebiatowie odbył się sejm, podczas którego decyzją książąt Barnima XI i Filipa I uchwalono przyjęcie w Księstwie Pomorskim reformacji. Miało to swoje konsekwencje w postaci konfiskaty dóbr kościelnych i klasztornych na rzecz domu książęcego. Także dobra klasztorów w Białobokach i Trzebiatowie zastały przejęte przez panujących. Norbertankom z klasztoru trzebiatowskiego zezwolono na dożywotnie użytkowanie zabudowań. W $1618 \mathrm{r}$. budynki poklasztorne zajęła księżna Zofia, która jako wdowa po Filipie II wyjechała ze Szczecina i w 1619 r. przeprowadziła adaptację budowli na swoją rezydencję. Mieszkała w niej do 1658 r. W latach 1618-1648 wojna trzydziestoletnia, okupacja szwedzka, a potem brandenburska przyczyniły się do regresu gospodarczego i znacznego zubożenia mieszkańców. W 1679 r. pożar dokonał ostatecznych zniszczeń. Od tamtej pory miasto nie wróciło do dawnego znaczenia.

W 1725 r. król pruski Fryderyk I ustanowił Trzebiatów miastem garnizonowym. Od tego czasu w zabudowaniach poklasztornych stacjonował pułk dragonów.

Kolejny wielki pożar strawił miasto w 1747 r., po którym do końca XVIII w. trwała powolna odbudowa. Jednak nowa zabudowa była już uboższa, o skromniejszej architekturze. Konstrukcja budynków, niegdyś murowana, powstaje jako ryglowa, nawet w budynkach frontowych. Rozebrano wówczas średniowieczne bramy, które utraciły swoją funkcję obronną, splantowano wały i fosy, zamieniając je w ogrody warzywne. W XIX w. nastąpił rozwój przemysłu w postaci fabryki ceramiki budowlanej i fajansu, fabryki mebli, opakowań staniolowych. Rozwojowi przemysłu towarzyszyło poprowadzenie linii kolejowej oraz sieci dróg bitych. Nie odnotowano jednak wówczas silniejszego rozwoju zabudowy, która w XX w. do II Wojny Światowej sięgnęła jedynie przedmieść Gryfickiego i Kołobrzeskiego. Wiek XX to jednocześnie czas odkrycia zdrowotnego działania kąpieli morskich, co spowodowało rozwój miejscowości nadmorskich i pośrednio wpłynęło na rozwój turystyczny Trzebiatowa. Z działań wojennych miasto wyszło obronną ręką i jako jedyne w tym obszarze zachowało niemal wszystkie cenne obiekty o charakterze publicznym oraz znaczną ilość mieszczańskiej zabudowy mieszkalnej i gospodarczej. Zabudowa ta jako całość stanowi do dziś wartościowy zespół urbanistyczny, o wyraźnych walorach kompozycyjnych, wzbogacony dominantami, z zachowanymi obiektami będącymi świadectwem kształtowania poziomu kultury materialnej na terenie Pomorza. Z powyższej przyczyny w 1955 r. zespół Starego Miasta w Trzebiatowie został uznany za zabytek. 

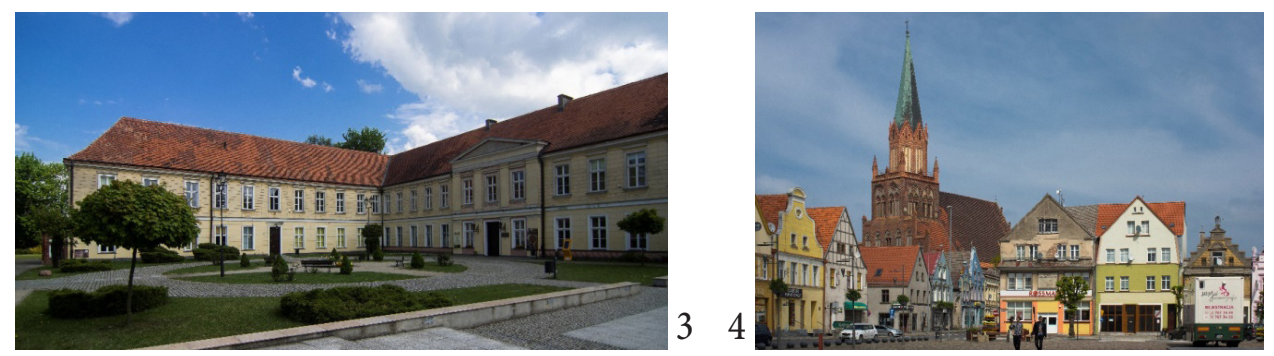

Fot. 3 Trzebiatów. Pałac, pierwotnie klasztor, obecnie siedziba Trzebiatowskiego Ośrodka Kultury (fot. C. Dubiel)

Fot. 4 Rynek Starego Miasta w Trzebiatowie, w głębi kościół pw. Macierzyństwa NMP (fot. C. Dubiel)

W granicach proponowanego wpisu jest 40 zabytków wpisanych indywidualnie do rejestru, wśród których znajdują się: kościół pw. Macierzyństwa NMP (fot. 4), obwarowania miejskie, kaplica św. Ducha, ratusz, pałac, domy i kamienice mieszczańskie, XVII-wieczne sgraffito na elewacji kamienicy przyrynkowej, zabytki techniki: elektrownia wodna i młyn gospodarczy. Ponadto jest tam ponad 100 obiektów objętych ochroną poprzez ujęcie w gminnej ewidencji zabytków.

\section{Zniszczenia wojenne i odbudowy miast Pomorza Zachodniego}

Trzebiatów jest wyjątkowym przykładem północnoeuropejskiego średniowiecznego miasta średniej wielkości zachowanego $\mathrm{w}$ swej autentycznej strukturze $\mathrm{w}$ tak dużym stopniu. $\mathrm{Na}$ Pomorzu Zachodnim zniszczenia wielu miast poniesione zarówno w trakcie działań wojennych jak i po II Wojnie Światowej, zatarły ich pierwotny obraz. Zniszczenia sięgające od 75 do 100\% dotknęły centra miejskie m.in. w Szczecinie, Goleniowie, Kamieniu Pomorskim, Stargardzie, Nowogardzie, Pyrzycach, Gryfinie ${ }^{14}$. Po wojnie miasta te ulegały przeobrażeniu na podstawie sporządzanych planów urbanistycznych, których cechą charakterystyczną było odstąpienie od zasady odbudowy i preferowanie zabudowy nowej, podporządkowanej obowiązującym rygorom formalnym i ekonomicznym. Ich nadrzędnym celem było dążenie do stałego obniżania kosztów budowy, co uzyskiwano poprzez wprowadzanie szczegółowych rozporządzeń i normatywów zmieniających się cyklicznie w kolejnych pięciolatkach. Głównie polegało to na obowiązkowym stosowaniu projektów typowych, katalogowych, o normatywnych wielkościach i strukturze, sytuowanych zgodnie ze współczesnymi wymaganiami dotyczącymi doświetlenia i przewietrzania mieszkań, wzajemnej odległości budynków, zieleni towarzyszącej oraz terenów rekreacyjnych. Niezbędny program usług podstawowych należało realizować na wydzielonych działkach $\mathrm{w}$ formie pawilonów ${ }^{15}$. Jako przykłady realizacji powyższych zasad można podać Stare Miasto w Pyrzycach, które na skutek działań wojennych praktycznie przestało istnieć, podobnie Kamień Pomorski, w którym zachował się ratusz staromiejski i jedna kamienica przyrynkowa lub Gryfice, które zachowały w swoim obrębie, obok kościoła i znacznej części

\footnotetext{
14 Latour S., 2005 r., s. 12.
}

15 Latour S., 2005 r., s. 16. 
murów obronnych, wiele domów mieszkalnych w pierzejach przyrynkowych i wzdłuż ciągów ulicznych. W Pyrzycach zdawnejzabudowy pozostałjedynie pierścień murów obronnych, korpus kościoła św. Maurycego oraz kościół św. Ducha. Odbudowa miasta polegała na wprowadzeniu na odgruzowany teren starego miasta nowej zabudowy o formach współczesnych i typowych rozwiązaniach, tworząc osiedle mieszkaniowe nie respektujące dawnych podziałów na kwartały i w ich obrębie podziałów katastralnych oraz pierzejowej zabudowy. W Kamieniu Pomorskim również postała nowa zabudowa $\mathrm{z}$ form typowych. Podjęto tu jednak próbę przywrócenia pierzei rynkowych usytuowanych wokół zabytkowego ratusza, jednak jedną pierzeję pozostawiono niezabudowaną, otwierając od strony północnej widok na Zalew Kamieński. W Gryficach natomiast nastąpiła sytuacja zgoła odmienna, gdyż zachowały one sporą część zabudowy pierwotnej, ta jednak nie poddawana bieżącym remontom i zaniedbana, chyliła się ku upadkowi. Jako że miasto to stanowiło powiatowy ośrodek administracyjny nastąpiła konieczność jego szybkiej rewaloryzacji. Na skutek przyjętych w latach 60 -tych projektów, w obliczu opinii, że restauracja istniejącej zabudowy jest nieopłacalna, całkowicie usunięto $z$ terenu starego miasta historyczną zabudowę wprowadzając $\mathrm{w}$ to miejsce typowe budynki klatkowe i punktowe z płaskim dachem, sytuowane w sposób przypadkowy. Stare miasto stanowi w konsekwencji zbiór budynków rozsianych na jego terenie, które nie tworzą żadnej spójnej kompozycji, a jedna $\mathrm{z}$ pierzei przyrynkowych została rozebrana i wypełniona współczesnym budynkiem administracyjnym przeznaczonym na siedzibę władz powiatowych ${ }^{16}$.

\section{Rewaloryzacja Trzebiatowa}

Powyżej opisane działania nie ominęły w pewnym stopniu również Trzebiatowa, którego część starego miasta, choć niewielka w porównaniu z innymi ośrodkami, uległa destrukcji. Dotyczy to czterech skrajnych kwartałów (spośród wszystkich 23 w obrębie murów obronnych), które począwszy od roku 1970 wypełniono nową zabudową blokową. Na szczęście po zrealizowaniu pierwszych dwóch budynków 5-cio kondygnacyjnych z płaskim dachem odstąpiono od tego typu zabudowy na korzyść niższych obiektów z wysokim dachem, sytuowanych równolegle do murów obronnych. Dzięki temu, choć zaburzony został podział katastralny w obrębie kwartałów, nie ucierpiała na skutek tej realizacji panorama miasta. Obiekty nie są również widoczne z rynku starego miasta. Równolegle prowadzone były planowe prace remontowe, uwzględniające wytyczne konserwatorskie, wykonywane w oparciu o indywidualne projekty. Odremontowano pierzeje rynkowe, kilka kamienic przy ul. Wojska Polskiego, mury obronne, pałac (fot. 3) i ratusz (fot. 2).

Odbudowano zachodnią pierzeję przyrynkową, z której pozostała jedna narożna kamienica. Zdecydowano odbudować ją, zachowując dawny podział własnościowy zgodny ze średniowiecznym podziałem katastralnym oraz formę pierwotnej zabudowy w postaci szczytowo usytuowanych kamienic wysokości 2,5 kondygnacji, przykrytych stromym dwuspadowym dachem. W przeciwieństwie do rozwiązań w innych miastach odbudowa ta spowodowała przywrócenie rynkowi jego pierwotnej skali i ogólnej formy urbanistycznej.

16 Latour S., 1981 r., s. 54. 


\section{Współpraca z Politechniką Szczecińską}

Trzebiatów, jak i inne miasta regionu, znalazł się w kręgu zainteresowań zarówno służb konserwatorskich, jak i Instytutu Architektury i Planowania Przestrzennego Politechniki Szczecińskiej. Dzięki porozumieniu uczelni z władzami miasta w pracowni projektowej Zakładu Teorii Architektury, Historii i Konserwacji Zabytków powstawały projekty rewaloryzacji miasta jako całości oraz poszczególnych kwartałów czy obiektów (fot. 5).

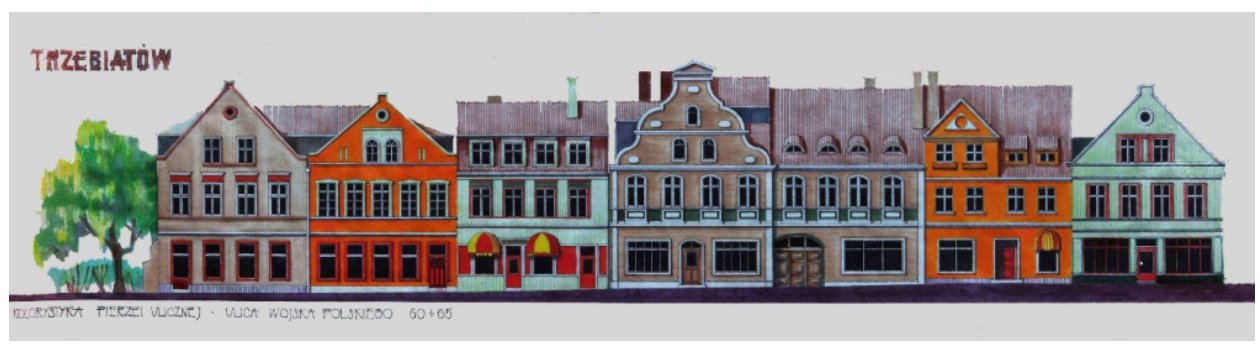

Fot. 5 Trzebiatów. Projekt kolorystyki pierzei od strony ul. Wojska Polskiego kwartału poddanego rewaloryzacji w latach 70-tych XX w. (archiwum rodziny Latour)

Stał się też Trzebiatów polem doświadczeń dla studentów architektury, którzy w ramach praktyk przedmiotowych organizowanych w latach 70-tych, przeprowadzali inwentaryzacje budynków położonych w granicach Starego Miasta, co stanowiło pomoc w ocenie ich stanu i przygotowaniu opracowań konserwatorskich ${ }^{17}$. Zadania z zakresu rewaloryzacji kwartałów staromiejskich były również przedmiotem projektów dyplomowych.

\section{Miejscowy plan zagospodarowania przestrzennego Trzebiatowa}

Plan rewaloryzacji miasta Trzebiatowa został sporządzony w 1996 r. przez zespół projektantów z Instytutu Architektury i Planowania Przestrzennego Politechniki Szczecińskiej pod kierownictwem Stanisława Latoura ${ }^{18}$. Opracowanie planu zostało poprzedzone rozpoznaniem wszystkich uwarunkowań, tj. wykonaniem szczegółowej inwentaryzacji urbanistycznej, architektonicznej, studium krajobrazu, studium ochrony i kształtowania panoram, fizjografii za szczegółową inwentaryzacją zieleni, oceną stanu technicznego zabudowy, rozpoznaniem struktury własności gruntów, studium komunikacji. Opracowano szczegółowe wytyczne konserwatorskie, ustalono funkcje dominujące dla poszczególnych obszarów, sformułowano sposób zagospodarowania poszczególnych fragmentów Starego Miasta, ustalono rygory ochronne oraz nakaz przekształceń rejonów zdegradowanych. Wyznaczono strefy ochrony konserwatorskiej, wskazano obiekty wpisane do rejestru zabytków oraz te, które wytypowano do wpisu. Zaproponowano podział na działki w poszczególnych kwartałach, co umożliwia Miastu prowadzenie odpowiedniej polityki obrotu gruntami.

Opracowanie to stało się podstawą zmiany miejscowego planu zagospodarowania miasta uchwaloną przez Radę Miasta Trzebiatowa 3 września 1996 r.

17 Latour S., 2005 r., s.18.

18 Kulesza-Szerniewicz E., 2016 r. 
Główne cele przedstawiono na wstępie:

1) ochrona zachowanych walorów kulturowych przestrzeni staromiejskiej i przywrócenie utraconych walorów przestrzeniom zdegradowanym;

2) zapewnienie ładu przestrzennego, ochrona walorów krajobrazowych i środowiska przyrodniczego;

3) zapewnienie prawidłowych standardów warunków mieszkaniowych;

4) dostarczenie miastu instrumentu, służącego prowadzeniu prawidłowej polityki obrotu gruntami.

\section{Wartości niematerialne}

W Trzebiatowie daje znać o sobie swoisty genius loci, coś, co sprawia, że to miejsce jest jedyne w swoim rodzaju. Mają na to wpływ wartości niematerialne jako nieodłączne współistnienie wartości materialnych miejsca. Składają się na nie zarówno te historyczne jak i współczesne.

1. Wartości historyczne:

- Obecność znaczących postaci mających wpływ na miasto, do których należą:

- Księżna Anastazja, córka Mieszka III Starego, żona księcia Bogusława I, która sprowadziła do Trzebiatowa norbertanki;

- Książę Barnim I i jego syn Bogusław IV, którzy nadali miastu lubeckie prawo miejskie;

- Jan Bugenhagen, propagator nauk Lutra, rektor trzebiatowskiej szkoły miejskiej, uczestnik sejmu trzebiatowskiego w 1534 r., na którym decyzją książąt Barnima XI i Filipa I przyjęto w Księstwie Pomorskim reformację;

- Księżna Zofia, wdowa po Filipie II, która przejęła klasztor ponorbertański i przebudowała go na swoją rezydencję;

- Król pruski Fryderyk I, który ustanowił Trzebiatów miastem garnizonowym;

- Księżna Maria Anna Czartoryska, żona księcia Fryderyka Ludwika von Württemberg, którego wujem był król Prus Fryderyk;

- Lyonel Feininger, amerykański malarz i grafik, który zachwycił się nadmorskim Mrzeżynem i Trzebiatowem pozostawiając tego ślad w swojej twórczości;

- Stanisław Latour, architekt, profesor Politechniki Szczecińskiej, autor projektu rewaloryzacji Starego Miasta w Trzebiatowie oraz szef zespołu opracowującego raport dotyczący Trzebiatowa na zlecenie Ministerstwa Kultury w ramach programu Ratowanie Miast Historycznych ${ }^{19}$;

19 Raport dotyczący przebiegu procesu rewaloryzacji miasta Trzebiatowa został opracowany w ramach programu resortowego Ministerstwa Kultury i Sztuki na zlecenie Wojewódzkiego Konserwatora Zabytków w Szczecinie przez zespół autorski z Instytutu Architektury i Planowania Przestrzennego Politechniki Szczecińskiej w składzie: Stanisław Latour, Helena Freino, Anna Borkowska-Koniewicz, Agnieszka Latour, Waldemar Marzęcki, Kazimiera Kalita-Skwirzyńska; w zasobach archiwum autorki. 
- Szczególne wydarzenia historyczne - 1534 r. Sejm Trzebiatowski, podczas którego decyzją książąt Barnima XI i Filipa I oraz zgromadzonych przedstawicieli stanów pomorskich uchwalono przyjęcie w Księstwie Pomorskim reformacji.

2. Wartości współczesne:

- Spotkania czterech świec - miejsce spotkań czterech kultur i religii: rzymskokatolickiej, grekokatolickiej, prawosławnej i ewangelickiej odbywających się w Trzebiatowskim Ośrodku Kultury ${ }^{20}$.

- Spotkania Pomorskie - organizowane corocznie przez Trzebiatowski Ośrodek Kultury spotkania naukowców, historyków sztuki, archeologów, przedstawicieli środowisk kultury i sztuki oraz miłośników Trzebiatowa na konferencjach poświęconych Trzebiatowowi i ziemi trzebiatowskiej ${ }^{21}$.

- Aktywne uczestnictwo mieszkańców w wydarzeniach kulturalnych poszerzających wiedzę na temat historii miasta i regionu, świadczące o utożsamieniu się z nim i głębokiej świadomości jego dziedzictwa.

\section{Pomnik Historii - spodziewane perspektywy dla miasta}

- Nobilitacja miasta, podwyższenie jego wartości i znaczenia, co może mieć wpływ na rozwój niektórych jego obszarów np. turystyki;

- Powód do dumy mieszkańców oraz większe zrozumienie dla potrzeby ochrony zabytkowego obszaru i zarazem wzmocnienie wobec niego postawy opiekuńczej;

- Wzmocniona opieka służb konserwatorskich - WUOZ i NID, realizowana poprzez planowany program monitorowania pomników historii;

- Dodatkowa punktacja przy pozyskiwaniu zewnętrznych środków finansowych.

\section{Konkluzja}

Należy bezspornie stwierdzić, że osiem lat oczekiwania na decyzję Ministerstwa Kultury, nawet jeżeli wymaga ona dodatkowego postępowania wyjaśniającego, to bardzo długo. Zwłaszcza, że nie jest ono jeszcze zakończone. Wnioskodawca nie jest informowany na jakim etapie jest rozpatrywanie wniosku i z jakiej przyczyny trwa tak długo. Na pytania otrzymuje ogólnikowe odpowiedzi. Z powodu braku komunikacji nie ma możliwości wpłynięcia na rozstrzygnięcie w postaci np. uzupełnienia wniosku. Świadczy to o niedoskonałości procedur przyznawania tytułu, które być może powinny zostać zrewidowane i skorygowane.

W przekonaniu autorki miasto Trzebiatów z racji swoich szczególnych walorów spełnia kryteria stawiane pomnikom historii. Nie ustępuje takim miastom - pomnikom historii jak Paczków czy Stary Sącz, choć to porównanie nie może być traktowane dosłownie ze względu na inny charakter oraz genezę wymienionych zabytków. Wartość Trzebiatowa polega na jego zachowanym

\footnotetext{
20 https://kultura.trzebiatow.pl/.

${ }^{21}$ https://kultura.trzebiatow.pl/trzebiatow-spotkania-pomorskie/.
} 


\section{Agnieszka Latour}

w nieomal nienaruszonym stopniu średniowiecznym układzie urbanistycznym, czytelnym podziale katastralnym oraz zachowanej na niespotykaną skalę na Pomorzu Zachodnim historycznej tkance miejskiej. Z tych to powodów warte jest tej szczególnej nobilitacji. 


\section{Bibliografia}

Latour S., 1981 r., Rewaloryzacja zabytkowych miast na Pomorzu Zachodnim, wyd.: Państwowe Wydawnictwo Naukowe, Warszawa - Poznań 1981.

Latour S., 2005 r., Przemiany w przestrzeni miast zabytkowych na Pomorzu Zachodnim po II Wojnie Światowej, [w:] Sztuka XX wieku w Szczecinie i na Pomorzu Zachodnim. Przemiany $i$ kontynuacje, Materiały z Seminarium Naukowego Szczecińskiego Oddziału SHS, Szczecin 1819 listopada 2005 r., wyd.: Muzeum Narodowe w Szczecinie, 2008 r.

Kulesza-Szerniewicz E., 2010 r., Zagospodarowanie dziedzictwa kulturowego Trzebiatowa problemy i perspektywy, [w:] Trzebiatów - spotkania pomorskie 2009, red. J. Kochanowska, Pruszcz Gdański - Trzebiatów, s.231-237.

Kulesza-Szerniewicz E., 2016 r., Ochrona krajobrazu kulturowego w planowaniu przestrzennym na przykładzie gmin powiatu gryfickiego, [w:] Trzebiatów - spotkania pomorskie 2015, wyd.: Trzebiatowski Ośrodek Kultury, 2016 r.

Kulesza-Szerniewicz E., 2018 r., Stare Miasto w Trzebiatowie - ochrona zabytkowych wartości a planowanie przestrzenne, [w:] Trzebiatów - spotkania pomorskie 2017, red. J. Kochanowska, Trzebiatów, s.175-191.

Ślaski K., 1960 r., Podziały terytorialne na Pomorzu w XII-XIII w., Poznańskie Towarzystwo Przyjaciół Nauk, t. 18, z. 4.

Klempin R., 1868 r., Pommersches Urkundenbuch.

Karta obiektu zabytkowego - Stare Miasto w Trzebiatowie, 2014 r.; w zasobach WUOZ w Szczecinie.

Wniosek o przyznanie tytułu Pomnika Historii złożony do MKiDN za pośrednictwem ZWKZ.

Miejscowy plan zagospodarowania miasta w formie planu rewaloryzacji Starego Miasta, Dz. Urz. Województwa Szczecińskiego nr 3, z dnia 12 marca 1997 r.

Strona internetowa NID: https://www.nid.pl/pl/Dla_wlascicieli_i_zarzadcow/opieka-nadzabytkami/pomniki-historii

Strona internetowa Trzebiatowskiego Ośrodka Kultury: https://kultura.trzebiatow.pl/ 
